\title{
Integrating Indigenous Knowledge Research System (IKRS) and/ with Livestock Health Intervention Program to Complement Natural Resource Conservation
}

\author{
Ravikumar RK ${ }^{1}$, Vivek Kumar ${ }^{1 *}$, Laishram Yelhounganba Khuman ${ }^{1}$, Amol S Kinhekar, Devesh \\ THAKUR $^{2}$, VIPIN KUMAR ${ }^{1}$
}

\begin{abstract}
${ }^{1}$ National Innovation Foundation-India, Satellite complex, Jodhpur Tekra, Premchand Nagar Road, Satellite, Abmedabad, Gujarat-380 015; ${ }^{2}$ Dr. G. C. Negi College of Veterinary $\Xi^{2}$ Animal Sciences, Palampur, Himachal Pradesh - 176062, India.
\end{abstract}

\begin{abstract}
Worldwide stakeholders have acknowledged the role of Indigenous Knowledge Research System (IKRS) as cost effective, readily accessible and sustainable solution. Several studies reflect documentation and assessment of indigenous veterinary practices. However, limited research studies have been conducted to demonstrate suitable model for integrating IKRS with livestock health intervention system. This exploratory research study explains utilization of IKRS in Gujarat and Manipur state of India. The study revealed that farmers were keen to embrace IKRS due to availability of practices, failure of conventional medications against certain ailments. Farmers were found to be aware of medicinal properties of plants, and acclaimed knowledge holders in usage of IKRS in their regions. These indigenous technologies or practices were location specific and innovative. The findings reiterated that State Department of Animal Husbandry (SDAH) alone cannot provide quality livestock health care. The support of SDAH, dairy societies and university research system is paramount for conservation and wider diffusion. Advancement of systemic response to indigenous healers can enable them to organize and acknowledge each other's effort through co-operative spirit. These frugal innovations can complement existing health care system and enhance livestock welfare, if only natural resources are conserved. Willingness, abilities of knowledge holders, farmers being part of research system, their experimental learning and knowledge of medicinal plants have to be reflected while designing disease control programs. Non-monetary incentives and diverse ways of engagement with knowledge holders are pre-requisite for sustaining, scaling knowledge systems. A suitable framework is shared for invigorating IKRS through utilizing, conserving natural resources with the help of existing formal and informal veterinary institutions.
\end{abstract}

Keywords | Biodiversity, Frugal innovation, Integration, Indigenous knowledge, Livestock

Editor $\mid$ Alok Sharma, Dr. G. C. Negi College of Veterinary \& Animal Sciences, Palampur, Himachal Pradesh, India.

Special Issue | 1(2016) "Welfare issues, Environment, Societal learning and Innovation in Livestock Science"

Received | July 02, 2016; Accepted | July 18, 2016; Published | July 21, 2016

${ }^{*}$ Correspondence | Vivek Kumar, National Innovation Foundation-India, Satellite complex, Jodhpur Tekra, Premchand Nagar Road, Satellite, Ahmedabad, Gujarat - 380 015, India; Email: vivekkumar@nifindia.org

Citation | Ravikumar RK, Kumar V, Khuman LY, Kinhekar AS, Thakur D, Kumar V (2016). Integrating indigenous knowledge research system (IKRS) and/with livestock health intervention program to complement natural resource conservation. Adv. Anim. Vet. Sci. 4(1s): 32-42.

DOI | http://dx.doi.org/10.14737/journal.aavs/2016/4.1s.32.42

ISSN (Online) | 2307-8316; ISSN (Print) | 2309-3331

Copyright (C) 2016 Ravikumar et al. This is an open access article distributed under the Creative Commons Attribution License, which permits unrestricted use, distribution, and reproduction in any medium, provided the original work is properly cited.

\section{INTRODUCTION}

F ood security and opportunity for gainful employment has been challenge with increasing population pressure. In this context, the demand for animal products will be doubled by 2050 and it will be felt in Asia, Africa and Latin-America (NJAS, 2013).Thus livestock production system is an important sector for specialized as well as small holder farming system. However, livestock manage- ment has been difficult with changing rural context such as limited or lack of grazing land (Doumbia et al., 2012), availability of medications (Usha et al., 2016), increased cost (Ritter et al., 2012), disease resistance (Nabukenya et al., 2014; Raot et al., 2016) and emergence of challenges in public health. The social concern of climate change and contribution of livestock in production of greenhouse gas emissions have to be addressed. More attention has been given to enhance ability of society to cope with environment 
challenge (Folke and Gunderson, 2006). Environmental performance of this sector has to be improved by adopting climate friendly technologies (Kaufmann, 2015). There is an urgent requirement for wide-scale innovation that can be sustainable and that also improves livelihood and food security (Notenbaert et al., 2016). Activities have to be reinforced to comprehend knowledge of informal system in protecting environment (Munda et al., 2016). Enhanced incidence of ailments such as mastitis, tick infestation and escalating cost to control them need to be minimized through suitable intervention. Public veterinary system has to play pivotal role in these regions of world. In India, State Department Animal Husbandry (SDAH) is responsible for livestock health care and farmers consider them as major source of information (Ravikumar and Chander, 2011). Studies in Africa and elsewhere indicated inadequate veterinary service and lack of low cost alternative technologies as impediment in overcoming Coccidiosis, Newcastle disease in poultry production system (Getachew et al., 2015; Shamim et al., 2015). Similarly, in animal production system tick and endoparasite infestations are severe problem affecting livestock worldwide (Kadivendi et al., 2015; Khoramian et al., 2014). There exist a necessity to look for environment friendly technologies for livestock welfare and productivity (Periyaveeturaman et al., 2015).

Different production systems influence decision of farmers to implement disease control strategies (Jemberu et al., 2015). Recognizing problems at community level is an essential step for supporting any interventional activities (Ravikumar et al., 2016). Dependence of farmers over dairy co-operative societies may be considered for enhancing utilization of location specific technologies under smallholder production system (Ravikumar et al., 2015). Recent trends indicate that frugalization have more potential as customer requirements have strong regional characterization and industrial response were not structured (Colledani et al., 2016).Local communities need to be in forefront towards knowledge creating, distribution and sharing system (Lwoga et al., 2010). Kolawole et al. (2007) shared that indigenous system provided platform for local level decision. People's capabilities and social connections were critical criteria while devising suitable strategies for utilization of natural resources (Sangha et al., 2015). Creative expressions of informal society can provide solutions and accessibility to appropriate technology (Kumar et al., 2013). They can empathize and understand to develop solutions through co-creation among themselves (Surtia et al., 2016). It is essential to identify new approaches where farmers can participate equally for agricultural development (Yacob et al., 2012).

Linear model of livestock health strategy comprising of technologies originating from research stations and im- plemented with the help of state animal husbandry departments have to be reviewed. There is an urgent need to adopt, sustain and scale-up societal learning from creative and experimental farmers, knowledge holders under IKRS. These livestock production systems are traditionally supported by plant based native knowledge system so as to meet their location specific need (Singh and Sureja, 2006). However, preservation of natural habitats in developing countries has been a daunting task given rapid population growth and agricultural expansion (Aluja et al., 2014). Initiatives to conserve indigenous knowledge is paramount as loss of this vital knowledge system affects rural communities (Dwebaa and Mearns, 2011).

Ability to understand and utilize Indigenous Knowledge Research System (IKRS) for overcoming inadequacies has been limited. These technological solutions from non-formal innovators can be diffused through open sharing (Abrol and Gupta, 2014). Farmers adopt technologies derived from IKRS due to limited access for modern veterinary facilities (Ghorai et al., 2016). At least 80 percent of people use these knowledge systems in developing countries (Balaji and Chakravarthi, 2010). The projected growth of these low end technologies were higher than high end technologies (Ravikumar et al., 2015a). It has to be noted that carriers of technology are as equally important as technology in improvising agricultural situation (Brian and Chatterton, 1982). Thus there is a need to examine the role of knowledge holders apart from other human resource involved in technology transfer. Emphasis have been made for participatory approaches to incorporate learnings from indigenous people while planning, conducting research (Kaya and Seleti, 2013). More research has to be undertaken to understand relationship between knowledge integration and strengthening social-ecological context (Bohensky and Maru, 2011). Lack of knowledge or prior experience with alternative therapies can influence willingness of farmers to treat for ailments (Richert et al., 2013). Diversified approaches are needed in protecting these plant based knowledge system as welfare of livestock provides income generating activity. This is more significant among vulnerable members of society who mostly rear small ruminants, equines and backyard poultry. Livestock sector provides opportunity for women in gainful employment as well (Ramkumar et al., 2004). Gupta (1984) opined that public system have to play appropriate role to match expectation of backward regions. The realization has happened lately that in order to avail extremely affordable technologies society has to learn from green grassroots innovators and traditional knowledge holders (Gupta, 2012). Strategies have to be advocated in utilization of niche specific technologies, and enhancing their availability in farmers field (Ravikumar et al., 2015b). The present study made an attempt to strengthen knowledge system in their field for facilitating livestock health care through natural resources. 


\section{MATERIALS AND METHODS}

An exploratory research study was carried out to gain relevant knowledge and understanding in utilizing and reviving natural resource based livestock health intervention under IKRS (Kerlinger, 2004). Extensive field studies were conducted in the state of Gujarat and Manipur, India during 2013-2015. The information was gathered over a period of time in different parts of India to unearth interactions under IKRS like social influence, community network, and social rewards apart from livestock welfare. The study tried to provide intellectual space for local knowledge systems so as to advance stakeholder's niche advantages. This is as per methodology indicated by Minh et al. (2014). The study tried to identify critical role of plant based IKRS towards livestock health care service delivery system. The paper also shared a conceptual framework for frugal livestock innovation management elements comprising knowledge holders, farmers and formal veterinary institutions in effective utilization of natural resources.

\section{STUdy Area}

Seven localities purposively selected from two districts in Gujarat and one district in Manipur, India were the area of study. Observations were recorded based on field experimentation at villages viz., Amarapur, Ambod, Limbodara and Indranagar of Mansa Taluk, Gandhinagar district and Hadida of Saverkundla Taluk, Amreli district, Gujarat. Similarly prevailing knowledge systems were identified in two villages viz., Heinoubok Awang and Oinam Bazar in Nambol region of Bishnupur district, Manipur. Interaction with the members of these communities was made through a community meeting among knowledge holders. Necessary efforts were made and observations recorded through village meetings, interpersonal interactions so as to understand nature of participation and organizing ability among them.

\section{Method of Implementation}

The observations and inference were drawn to manage livestock ailments through plant based medications. These meetings were organized in each village during and after intervention with indigenous medications to treat livestock ailments. During these meetings relevance of natural resources in addressing specific problem faced by farming. community towards control of parasitic infestation (ectoparasite and endoparasite), mastitis in livestock, and organizing ability of knowledge holders were examined and inferred.

\section{RESULTS AND DISCUSSION}

Reluctance of Farmers to Adopt Scientifically Known Technologies: Control OF Worm INFESTATION

Productivity of livestock is affected by common problems like endoparasite infestation. Package of practices and simple measures of administration of anthelmintic bolus has been the strategy of SDAH as well as dairy societies. In the study region villagers were not far off from their dairy society and were aware of clinical symptoms of affected animals like diarrhoea. However, they could not ensure required medication and were found reluctant to seek, adopt common technological products from dairy society. This is in concurrence with Gupta (2016) who observed that the people were not able to access affordable innovations. This may be due to lack of social interaction between service provider and end users. Brian and Chatterton (1982) confirmed that during technology transfer process role of farmers was underestimated. During this period, research team visited their premises, examined their animals and shared clinical observations. Villagers readily agreed for community meeting and discussed modalities of implementing new intervention strategy. Members of these community voluntarily offered their affected animals for treatment with indigenous veterinary medications. Two herbal medications based on knowledge of Shri Dayabhai Bharwad and community knowledge had provided relief to farm animals (Bharwad et al., 2015; Gaikwad et al., 2015).

During experimentation it was observed that farmers did not differentiate conventional or indigenous technologies during application of intervention. These are characteristics of subsistence farming under small holder production system. The successful intervention in treatment of endoparasite infestation in farmer's field through IKRS reinforces belief that frugal technologies can be adopted to control ailments. It is the role of local institutions who can provide catalytic power for advancement of any technology. The medicinal values of these plants were known to farming community either through historical context or by understanding the specific utility in control of ailments. These plants are locally available and community was in know of these plants and their usage. Nabukenya et al. (2014) indicated that majority of farmers believed these practices as effective, safe and therefore did not standardize dosage. Several studies have documented them and useful knowledge has been retained (Ritter et al., 2012). Livestock owners favoured indigenous knowledge due to availability of flora, cost effectiveness and being compatible to their system. This is in concurrence with Singh and Chauhan (2010) and Manoj et al. (2012). It was found that even known functional role of medicinal plant based IKRS remained unexplored at end users level. Some regions in the world like Mediterranean are yet to explore this knowledge system as it is more oriented towards specialized research (Castel et al., 2003). The availability of market based technology transfer works fairly well in regions that have better purchasing power (Hiremath et al., 2006). It is true that these systems try to optimise available resources (Rangnekar, 2011) and therefore there is a need for SDAH and 
other veterinary institutions to engage farmers in adopting IKRS based disease control measures for wider diffusion.

\section{How to Access Alternative Technology when Package of Practices Fail? Control of Tick} INFESTATION

Technologies are mostly derived to overcome specific etiological agent and to maximize profit. Industry approaches clientele based on these objectives and formal institutional stakeholders provide feedback on effectiveness of product. Investigations in the study regions revealed that farming community continuously adopted conventional medications to overcome tick infestation. Re-infestation of ticks after adopting scientific package was noticed within duration of thirty days. Farmers were compelled to call veterinary resource personnel at different times and faced with emotional difficulties in control of ticks (Kadivendi et al., 2015). There was no reluctance to purchase of medicines against tick infestation though farmers were aware of reoccurrence. They were ready to pay not only cost of product but also resource personnel's support. Under such circumstances, frontline veterinary personnel's and farmers were found to be helpless. It was challenging situation for frontline service providers as appropriate scientific technologies were not available. Modern technologies are often designed through efficacy study at specific location and not necessarily multi-location trials. These features indicated that development or availability of alternate technologies through conventional channel of distribution may not be quick and economical. These medications at farmer's region were not meeting their requirements and community incurred more loss. The challenge was to address welfare issues of livestock population that spreads over wider geographical area under different production systems. Thus public system needs to act swiftly to minimize unwarranted effects of synthetic acaricide Infact, drawbacks of intensive livestock production has been debated and research opinions shared for sustaining livestock farming with social concerns (NJAS, 2013).

In agricultural system, technological innovation and technical change can happen through learning by doing and modification of traditional practices (Jain and Verloop, 2012). A polyherbal spray preparation for control of tick infestation that consists of neem (Azadirachta indica A Juss) locally called as Limbado and Monks Pepper ( $\mathrm{Vi}_{-}$ tex negundo L.), locally called as Nagod was shared among villagers. Demonstrations were conducted to showcase in-situ preparation of standardized formulation as per $\mathrm{Ra}$ vikumar et al. (2015c). The acaricide property of both ingredients was widely known and farmers started adopting this preparation immediately. Few farmers acted as information gate-keepers before entire community recognized and adopted herbs based on no cost locally available solu- tion. During implementation, it was found that both men and women farmers operated as information gate-keepers. Social benefit was derived by rural communities in control of tick infestation based on natural resources (Kumar and Ravikumar, 2016). This led to launch of national campaign in control of tick infestation through low cost, locally available (LCLA) environment friendly solutions. The implications of control of ticks was not only limited to it, but beyond as they act as vector for economic ailments. The common knowledge of society has to be braced for enhancing scope of social interactions and trust among institutions. Thus such experimental models based on open source technological intervention need to emerge in-order to effectively use IKRS through frugal solutions. Community based validation exercise lends credibility and reinforce location specific knowledge systems. This is in concurrence with Shen et al. (2010) who opined that IKRS can minimize input cost for small holder farming system. This approach may enhance rate of adoption of socially acceptable medications in control of livestock ailments (Raot et al., 2016). These illustrate that the method of technology transfer has to be reoriented in scaling up of IKRS through these models of engagements.

\section{Who can Sustain IKRS and Creative Spirit of} Informal Society? Control of Mastitis

The higher use of IKRS is due to low cost and no side effect of these preparations (Parthiban et al., 2016). The study was conducted by field experimentation with help of knowledge holders and farmers through social mobilization. In majority of indigenous research approach, knowledge holders did not get desired opportunity to get feedback of their technology and to share their experimental experience. However, they are the major actor in the entire value chain of IKRS. Similar observations were reported by Devaki and Mathialagan (2015). An experimental research study at farmer's field for testing indigenous medication against mastitis revealed a refreshing approach. New knowledge was gained upon sharing scientific test results with community and knowledge holder (Devgania et al., 2015). Formal institutions need to gear up to evaluate IKRS scientifically at farmer's situation. This involves changes in institutional arrangements to seek research priorities and act as interface for technology transfer. Dorado-García et al. (2015) referred that antimicrobial use has to be reduced in food producing animals since it enhances prevalence of disease resistant bacteria. There is a necessity to bring visible evidence for sustaining IKRS as quickly as possible. Henceforth new means of identifying knowledge and utilizing them have to be explored.

The identification of novel practice was influenced by factors such as interaction among farming communities, experimental knowledge of individual knowledge hold- 
er outside formal system and process of sharing scientific evidence at farmers premises. Non- monetary incentive through acknowledging and recognizing knowledge holder by community had played role. These social values are paramount to sustain and to continue sharing of IKRS for future generation. Village level veterinary institutions can play key role in identifying these healers. These are essential component of well-functioning of institutions as it is based on trust. Studies call for leveraging link between healers and veterinary resource personnel's for sustaining this knowledge system (Tiwari and Pande, 2010). Fostering association between indigenous and formal institutions is crucial for sustaining natural resources (Alexander et al., 2011). These innovation process share commonalities of non-linear model as discussed by Mikhaylova (2014). Further, technologies developed under IKRS may address hitherto unserved consumers in developed countries who are increasingly aware of cost (Simula et al., 2015).

\section{Capacity of Knowledge Holders to Organize}

Themselves: Formation of Knowledge Network Backyard poultry rearing is a common practice in the regions of Manipur, India. It is an important income generating activity among small farmers and for food security. A community meeting was planned in the villages of Heinoubok Awang and Oinam Bazar, Nambol, Bishnupur district, Manipur. The purpose of the meeting was to share, discus identified novel herbal practice and to explain scientific validation of indigenous poultry medication against coccidiosis in poultry. These meetings were held on 28th February 2013 at Heinoubok Awang as well as in Oinam Bazar. Knowledge holders at Heinoubok Awang acknowledged widely prevalent usage of herbal medication in treatment of poultry ailment. They were ready to organize themselves and to meet other knowledge holders away from their village at Oinam Bazar. Knowledge holders from two different villages had discussed and respected each other's wisdom in treatment of poultry ailment. During these interactive meeting, members of the community deliberated and worked out representatives for recognizing, scaling up of their system of knowledge. These features illustrate that creative community can use and understand prevalent wisdom in their vicinity. In most regions, it was observed that farming community did not empathise on individual merit but readily acknowledged the role of community as a whole. This evidence is important as co-operative spirit of society have to be harnessed in overcoming challenge of providing quality livestock health care. This helped in establishment of knowledge holder's network through mutual respect. This is one of the few studies to narrate requirement to share value added knowledge and to strengthen healer's network. Similar observations were noted by Raot et al. (2016) wherein engagement with creative communities help in formation of knowledge network. These meetings enabled participation of women knowledge holders as they need not to travel long distance. This was in agreement with Kumar and Ravikumar (2016a). Medicinal value of these herbs can be protected by supporting such creative community groups through socially relevant research. Institutional mechanisms need to gear up for better utilization of these natural resources for availing affordable solution at farmer's doorstep.

Table 1: IKRS towards livestock welfare and productivity

\begin{tabular}{|c|c|c|c|c|c|}
\hline \multirow[t]{2}{*}{ SN } & \multirow[t]{2}{*}{ Nature of intervention } & \multicolumn{4}{|c|}{ Livestock disease conditions } \\
\hline & & Ectoparasite & Endoparasite & Mastitis & Coccidiosis \\
\hline 1 & IKRS based on herbs & Y & Y & Y & $\mathrm{Y}$ \\
\hline 2 & Economically important to farmers (IGA*) & Y & $\mathrm{Y}$ & $\mathrm{Y}$ & $\mathrm{Y}$ \\
\hline 3 & $\begin{array}{l}\text { Important for food security and human welfare } \\
\text { through village production system }\end{array}$ & Y & Y & Y & $\mathrm{Y}$ \\
\hline 4 & $\begin{array}{l}\text { Very well-known but unnoticed by service provider } \\
\text { and farmer }\end{array}$ & $\mathrm{Y}$ & $\mathrm{Y}$ & $\mathrm{X}$ & $\mathrm{X}$ \\
\hline 5 & Unable to access quality veterinary service & Y & $\mathrm{Y}$ & $\mathrm{Y}$ & Y \\
\hline 6 & Widely prevalent & $\mathrm{Y}$ & Y & $\mathrm{Y}$ & $\mathrm{Y}$ \\
\hline 7 & Availability of preventive measures such as vaccine & $\mathrm{X}$ & $\mathrm{X}$ & $\mathrm{X}$ & $\mathrm{X}$ \\
\hline 8 & Imminent requirement for clean technologies & $\mathrm{Y}$ & $\mathrm{Y}$ & $\mathrm{Y}$ & Y \\
\hline 9 & Trial conducted at farmers field under IKRS & $\mathrm{Y}$ & $\mathrm{Y}$ & $\mathrm{Y}$ & NA \\
\hline 10 & Engagement of farmers before start of intervention & $\mathrm{Y}$ & $\mathrm{Y}$ & $\mathrm{Y}$ & NA \\
\hline 11 & $\begin{array}{l}\text { Readiness to be part of experimentation by observing } \\
\text { livestock welfare }\end{array}$ & Y & Y & $\mathrm{Y}$ & NA \\
\hline 12 & $\begin{array}{l}\text { Observation shared by farmers to research team } \\
\text { under IKRS }\end{array}$ & $\mathrm{Y}$ & $\mathrm{Y}$ & $\mathrm{Y}$ & $\mathrm{Y}$ \\
\hline
\end{tabular}

Y: Yes; X: No; NA: Not applicable; * IGA-Income Generating Activity 
Can Livestock Health Care be complemented through Natural Resources? Illustrative EVIDENCES

Application of these knowledge systems through suitable approaches towards strengthening local systems were stressed (Balaji and Chakravarthi, 2010). It is also an established fact that inspite of modern medicine, the tradition of indigenous veterinary practices has survived till date (Mazars, 1994). In India, efforts of National Innovation Foundation-India in establishment of livestock innovation system through indigenous knowledge were shared. This include support extended by state department of animal husbandry (SDAH), recognition of knowledge holders by formal institutions by undertaking research, wider adoption and development of alternative technologies from IKRS (Kumar and Ravikumar, 2016). The creative spirit of farming community can be sustained by addressing their imminent problem through value added natural resources. Experimentation involving insitu incubation of IKRS have to be scaled up. This is vital for strengthening and sustaining experimental wisdom of knowledge holders and farmers. Technologies derived from IKRS can be classified as clean technologies and developmental policies have to focus on large scale implementation for climate smart production system. Similar views were shared in different countries towards management of climate change by smallholder farmers (Achiando and Birech, 2013; Ogalleh et al., 2012). However, conservation of agro-ecosystem and socio-cultural system is paramount to protect these practices (Verma, 2014).

Experimental research was conducted to overcome challenges of ectoparasite infestation, endoparasites, mastitis among farm animals and coccidiosis in birds (Table 1).
These ailments are economically important as they challenge productivity of livestock. They were commonly known to farmers, veterinary service providers but unnoticed due to less dramatic nature, lack of diagnosis at farmer's field and poor quality livestock health care. The constraint was due to different types of farming system as specialized livestock farms such as poultry units, organized cow sheds were distantly located from veterinary institutions. Herbal based IKRS where readily taken up by farmers to minimize impact of disease. The study also illustrated the need to engage with farmers before executing such intervention strategies. Herbal remedies shared by knowledge holders along with institutional support of animal husbandry department were found to be useful (Visvesvaran and Thirumalaiswamy, 2015). Similar observations by Ravikumar et al. (2016a) suggested measures to dovetail these technologies into animal health care system through on-farm applications. The need to support poultry production system through IKRS has been shared as well (Ghorai et al., 2016; Ravikumar et al., 2016b).

\section{IMPLICATIONS OF RESEARCH FINDINGS}

Type of InNovation Models for Reviving and Reinforcing Natural Resources through IKRS The potential of application of local knowledge were tried outside the region of documentation and found successful in treatment of livestock ailments (Periyaveeturaman et al., 2015; Patel et al., 2015; Bharwad et al., 2015). This reiterates that the skill of native system has to be protected for which models of utilization of IKRS by farming communities were shared (Table 2). These can be through Non Linear Innovation System [NLIS] and Open Source Innovation

Table 2: Disease control intervention through IKRS

\begin{tabular}{|c|c|c|c|c|c|}
\hline \multirow[t]{2}{*}{ SN } & \multirow[t]{2}{*}{ Nature of intervention } & \multicolumn{4}{|c|}{ Livestock disease conditions } \\
\hline & & Ectoparasite & Endoparasite & Mastitis & Coccidiosis \\
\hline \multicolumn{6}{|c|}{ I. Why IKRS? } \\
\hline 1 & Recurrent ability to develop resistant by etiological factors & $\mathrm{Y}$ & Y & Y & Y \\
\hline 2 & Multiple etiological factors contributing to ailment & Y & Y & Y & Y \\
\hline \multicolumn{6}{|c|}{ II. Nature of service delivery system through formal institutions such as SDAH } \\
\hline 3 & Availability of disease diagnosis facility & $\begin{array}{l}\text { Clinical } \\
\text { observation }\end{array}$ & $\begin{array}{l}\text { Clinical } \\
\text { observation }\end{array}$ & $\begin{array}{l}\text { Clinical } \\
\text { observation }\end{array}$ & $\begin{array}{l}\text { Clinical } \\
\text { observation }\end{array}$ \\
\hline 4 & Feedback to laboratory for confirmation of ailment & Limited & Limited & Yes & Limited \\
\hline 5 & $\begin{array}{l}\text { Physical mobility of key resource personnel at intervention } \\
\text { sites }\end{array}$ & $\begin{array}{l}\text { Natural } \\
\text { challenge }\end{array}$ & $\begin{array}{l}\text { Natural } \\
\text { challenge }\end{array}$ & $\begin{array}{l}\text { Natural } \\
\text { challenge }\end{array}$ & $\begin{array}{l}\text { Natural } \\
\text { challenge }\end{array}$ \\
\hline 6 & $\begin{array}{l}\text { Accessibility of farmer's in treating livestock within optimum } \\
\text { duration }\end{array}$ & $\begin{array}{l}\text { Natural } \\
\text { challenge }\end{array}$ & $\begin{array}{l}\text { Natural } \\
\text { challenge }\end{array}$ & $\begin{array}{l}\text { Natural } \\
\text { challenge }\end{array}$ & $\begin{array}{l}\text { Natural } \\
\text { challenge }\end{array}$ \\
\hline 7 & $\begin{array}{l}\text { Policy and support of research institutes towards effective } \\
\text { service delivery }\end{array}$ & $\begin{array}{l}\text { Limited, more } \\
\text { empathize on } \\
\text { diagnosis }\end{array}$ & Limited & Limited & Limited \\
\hline 8 & Type of Innovation model & OSIS, NLIS & NLIS & NLIS & NLIS \\
\hline
\end{tabular}

March 2016 | Volume 4 | Special issue 1 | Page 37 
system [OSIS] (Ravikumar and Kumar, 2015). In case of NLIS, novel technologies emerge from outstanding traditional knowledge holders or communities outside realms of formal research institutions. OSIS basic feature is to utilize existing knowledge of community that are commonly known and reinforce them through methods like admixture of several herbs to enhance impact, development of desired composition or formulation at farmer's field. This can enhance the scope for technology development from
IKRS and for wider diffusion of affordable, environment friendly technologies.

Suggested Framework for Mainstreaming IKRS to complement Plant Resource based Welfare System

The role of public system is significant in providing veterinary health service for disease prevention and productivity.

Table 3: Frugal livestock innovation management elements

$\begin{aligned} & >\text { Confirmation of livestock ailments through clinical symptoms and etiology } \\ & >\text { Solutions derived byapplication of technology through formal training,mostly relyon parametric experimentation } \\ & >\text { Organized and defined support system } \\ \text { Formal } & >\text { Less knowledge and skill to utilize plant based local resources } \\ \text { Institutional } & \text { No or less favourable working arrangement in scaling up or to provide handholding support for local wisdom } \\ \text { perception } & >\text { Keenness to solve livestock problem through medications derived from elsewhere } \\ & >\text { Lesser opportunity to innovate: Need for strengthening feedback loop } \\ & >\text { Regular training and reinforcement of formal knowledge system } \\ & >\text { Peer group pressure oriented towards scaling up of technologies acknowledged from outside } \\ & >\text { Lesser ability or lack of priority towards social mobilization for sustaining native wisdom/skills } \\ & >\text { Limited prospect of utilization of social learning for livestock welfare }\end{aligned}$

\begin{tabular}{|c|c|c|}
\hline \multirow{10}{*}{$\begin{array}{l}\text { Farmer's } \\
\text { perception }\end{array}$} & $>$ & Ability to identify nature of problem to certain extent and to seek resource personnel \\
\hline & $>$ & Understand value of plant based livestock welfare \\
\hline & $>$ & Require support for strengthening their established knowledge and utilization of local (natural) resources \\
\hline & $>$ & Capacity to recognize different plants in their vicinity \\
\hline & $>$ & Keenness to learn and solve problem based on availability of medications / resource constraints \\
\hline & $>$ & Readiness to be part of research system to generate innovative solutions \\
\hline & $>$ & $\begin{array}{l}\text { Livestock Service, Research System extend and reiterates formal knowledge system through awareness cam- } \\
\text { paign, training etc., }\end{array}$ \\
\hline & $>$ & Social influence are prevalent in utilization of sustainable technologies \\
\hline & $>$ & $\begin{array}{l}\text { Readiness to be part of social interaction as livestock activities (services) are based on cooperative nature eg., } \\
\text { Health camps, Dairy societies }\end{array}$ \\
\hline & $>$ & Proven capacity to imbibe social learning through support system \\
\hline \multirow{11}{*}{$\begin{array}{l}\text { Informal } \\
\text { Institutional } \\
\text { perception } \\
\text { [Knowledge } \\
\text { holder] }\end{array}$} & $>$ & Confirmation of livestock ailments through clinical symptoms for common ailments \\
\hline & $>$ & $\begin{array}{l}\text { Application of technology or practices through non-parametric experimentation with the help of locally } \\
\text { available solutions }\end{array}$ \\
\hline & $>$ & Has ability to organize themselves but requisite support system need to be defined to scale-up \\
\hline & $>$ & Has requisite knowledge, skill to utilize plant based local resources \\
\hline & $>$ & Empathetic in addressing social problems \\
\hline & $>$ & Sharing of novel technological solutions when faced with different and difficult situation \\
\hline & $>$ & $\begin{array}{l}\text { Reinforcement of indigenous knowledge system have to be strengthened: Presently there is lesser or no op- } \\
\text { portunity of reinforcement of native wisdom/skills }\end{array}$ \\
\hline & $>$ & Peer group pressure can enhance sharing of unrecognized experimental knowledge \\
\hline & $>$ & Demonstrated ability to be part of social mobilization and be part with formal institutions \\
\hline & $>$ & Non-monetary incentive have greater role in extending their service for livestock welfare \\
\hline & $>$ & Social learning is a part of IKRS ethics and spirit \\
\hline
\end{tabular}


Formal [state animal husbandry department, research system] and Informal [Knowledge holders, Community] institutions play significant role in enabling quality health care for livestock. The welfare of livestock depends on users, local wisdom (including knowledge holders, community bestowed with knowledge), institutions and technologies. The management system comprises of people, values, goals, knowledge, resources, monitoring and decision making opportunities (Keating and McCown, 2001). These systems act together through established process (formal institutions) or through inherent process (informal institutions) so as to provide desirable outcome. Any livestock intervention program has to understand and include these working arrangements. The study indicates that prevailing knowledge of community or healers can be utilized and welfare of livestock can be protected.

The fundamental feature of Indigenous Knowledge Research System is to depend on natural resources. Conserving natural resources is paramount to continue the tradition of utilizing environmental friendly plant based livestock health care system. This will help in implementing activities which can engage societal learning of farming community and to view necessary institutional changes. The physically demanding livestock farming activity pose distinct challenge to women in seeking veterinary services. The local knowledge of plants and readily accessible simple means of dispensation can minimize their drudgery. These gender sensitive welfare issues will enhance scope of reviving local tradition as it can be passed on to successive generations. The framework representing frugal livestock innovation management elements are indicated (Table 3 ). The study articulated the need for guarding organizing capacity of informal knowledge system and to sustain conservation efforts of natural resources under prevailing situation.

\section{ACKNOWLEDGEMENT}

We would like to acknowledge the outstanding Knowledge holders and livestock farmers in the study region.

\section{CONFLICT OF INTEREST}

Authors declare that they have no conflict of interest.

\section{AUTHORS CONTRIBUTION}

All authors contributed equally to the manuscript.

\section{REFERENCES}

-Abrol D and Gupta A (2014). Understanding the diffusion modes of grassroots innovations in India: a study of Honey
Bee Network supported innovators. Afr. J. Sci. Technol. Innovat. Dev. 6(6): 541-552.

-Achiando GA and Birech R (2013). The role of indigenous technical knowledge in the management of climate change by smallholder farmers. Afr. Crop Sci. Conference Proceed. 11: $685-689$.

-Alexander C, Bynum N, Johnson E, King U, Mustonen T, Neofotis P, Oettle N, Rosenzweig C, Sakakibara C, Shadrin V, Vicarelli M, Waterhouse J, Weeks B (2011). Linking indigenous and scientific knowledge of climate change. Bioscience. 61: 477-484. http://dx.doi.org/10.1525/ bio.2011.61.6.10

-Aluja M, Sivinski J, Driesche RV, Dadda AA, Guillen L (2014). Pest management through tropical tree conservation. Biodivers Conserv. 23: 831-853. http://dx.doi.org/10.1007/ s10531-014-0636-3

-Balaji NS and Chakravarthi PV (2010). Ethno-veterinary practices in India - a review. Vet. World. 3(12): 549-551. http://dx.doi.org/10.5455/vetworld.2010.549-551

- Bharwad D, Vasan V, Kinhekar AS, Kumar V, Ravikumar RK, Kumar V (2015). Therapeutic evaluation of indigenous veterinary medication for endoparasite infestation in bovines under field conditions. Indian J. Appl. Res. 5(4): 755-756.

-Bohensky EL and Maru Y (2011). Indigenous knowledge, science, and resilience: what have we learned from a decade of international literature on 'integration'? Ecol. Soc. 16(4): 6. http://dx.doi.org/10.5751/ES-04342-160406

-Brian and Chatterton L (1982). Failures in technology transferare farmers overlooked? Food Policy. May: 141-155.

-Castel JM, Menaa Y, Delgado-Pert'iñez M, Camúñez J, Basulto J, Caravaca F, Guzmán-Guerrero JL, Alcalde MJ (2003). Characterization of semi-extensive goat production systems in southern Spain. Small Ruminant Res. 47: 133-143. http://dx.doi.org/10.1016/S0921-4488(02)00250-X

- Colledani M, Silipo L, Yemane A, Lanza G, Bürgin J, Hochdörffer J, Georgoulias K, Mourtzis D, Bitte F, Bernard A, Belkadi F (2016). Technology-based product-services for supporting frugal innovation. Procedia CIRP. 47:126-131. http://dx.doi.org/10.1016/j.procir.2016.03.093

- Devaki K and Mathialagan P (2015). Animal husbandry traditional knowledge in Kancheepuram district. Int. J. Sci. Environ. 4(5): 1289-1295.

-Devgania BS, Khordia D, Chodvadiya MB, Patel R, Patel D, Kinhekar AS, Singh PK, Kumar V, Bhojne GR, Ravikumar RK, Kumar V (2015). Reverence of community towards grassroot livestock innovation: Responding to stakeholders need against sub-clinical mastitis in Amreli District, Gujarat, India. Adv. Anim. Vet. Sci. 3(12): 689-693. http:// dx.doi.org/10.14737/journal.aavs/2015/3.12.689.693

-Doumbia D, Van Paassen A, Oosting SJ, Van der Zijpp AJ (2012). Livestock in the rice based economy of Office du Niger: The development potential for increased croplivestock integration through multi-actor processes. Wageningen J. Life Sci. 60-63: 101-114. http://dx.doi. org/10.1016/j.njas.2012.07.002

-Dorado-García A, Graveland H, Bos MEH, Verstappen KM, Van Cleef BAGL (2015). Effects of Reducing Antimicrobial Use and Applying a Cleaning and Disinfection Program in Veal Calf Farming: Experiences from an Intervention Study to Control Livestock-Associated MRSA. PLoS One. 10(9): e0139536. http://dx.doi.org/10.1371/journal.pone.0139536

-Dwebaa TP and Mearns MA (2011). Conserving indigenous knowledge as the key to the current and future use of 
traditional vegetables. Int. J. Info. Manage. 31(6): 564-571. http://dx.doi.org/10.1016/j.ijinfomgt.2011.02.009

- Folke C, Gunderson L. (2006). Facing global change through social-ecological research. Ecol. Soc. 11(2): 43.

- Gaikwad SLR, Ramana DN, Solanki RP, Khatana LB, Gohil NK, Vasav NG, Patel P, Sahay NS, Patel J, Ravikumar RK, Singh PK, Kinhekar AS, Kumar V (2015). Efficacy of an indigenous veterinary medication to control endoparasite infestation in clinically diagnosed large ruminants affected with diarrhoea amongst field conditions: Gujarat, India. Eu. J. Exp. Biol. 5(5): 81-84.

- Getachew T, Kebede E, Ameha N, Terefe TA (2015). Village Chicken Husbandry Practice, Marketing and Constraints in Eastern Ethiopia. J. World's Poult. Res. 5(4): 104-108.

- Ghorai S, Ghorai N, Dutta L, Bera A, Ghorui S, Kinhekar AS, Ingle VC, Sonkusale P, Awandkar SP, Tembhurne PA, Kumar V, Ravikumar RK, Kumar V (2016). Protective and Immuno-Modulatory Effect of Low Cost Locally Available Technology from West Bengal, India under Indigenous Knowledge Research System. J. Immunol. Immunopathol. 18(1): 19-23. http://dx.doi.org/10.5958/09739149.2016.00003.4

- Gupta AK (2016). Gross roots Innovation, Penguin Books India Pvt. Ltd, Gurgaon, Haryana. Pp. 1-54.

- Gupta AK (2012). Innovations for the poor by the poor. Int. J. Technol. Learning Innovat. Dev. 5(1/2): 28-39. http:// dx.doi.org/10.1504/IJTLID.2012.044875

- Gupta AK (1984). Role of public enterprises in backward regions generating peasants' perspectives? Working Paper Number 511, Indian Institute of Management, Ahmedabad.

- Hiremath BN, Raju KV, Patel A (2006). Technology adoption and farm management in rural livelihood systems in Gujarat, in search of sustainable livelihood systems, Managing resources and change, Eds. Baumgartner R. and Hogger, R. Sage Publications India Pvt Ltd., New Delhi. Pp. 94-125.

-Jain A, Verloop, J (2012). Repositioning grassroots innovation in India's S\&T policy: From divider to provider. Current Sci. 103(3): 282-285.

-Jemberu WT, Mourits MCM, Hogeveen H (2015). Farmers' Intentions to Implement Foot and Mouth Disease Control Measures in Ethiopia. PLoS One. 10(9): e0138363. http:// dx.doi.org/10.1371/journal.pone.0138363

- Kadivendi M, Maheswari R, Ravikumar RK, Chauhan MM, Kinhekar AS, Kumar V, Kumar V (2015). Integrated Approach for Engaging Farming Community Opportunities and Challenges for Low Cost Inputs. Int. J. Agri. Innovat. Res. 3(6): 1691-1695.

-Kaufmann T (2015). Sustainable livestock production: Low emission farm- The innovative combination of nutrient, emission and waste management with special emphasis on Chinese pig production. Anim. Nutr. 1: 104-112. http:// dx.doi.org/10.1016/j.aninu.2015.08.001

- Kaya HO and Seleti YN (2013). African indigenous knowledge systems and relevance of higher education in South Africa. Int. Educat. J. Comparat. Perspect. 12(1): 30-44.

- Keating BA and McCown RL (2001). Advances in farming systems analysis and intervention. Agri. Syst. 70: 555-579. http://dx.doi.org/10.1016/S0308-521X(01)00059-2

-Kerlinger FN (2004). Foundations of behavioural research, $8^{\text {th }}$ Reprint, Surjeet Publications, Delhi, India. Pp. 395-409.

-Khoramian H, Arbabi M, Osqoi MM, Delavari M, Hooshyar H, Asgari M (2014). Prevalence of ruminant'sfascioliasis and their economic effects in Kashan, center of Iran. Asian
Pacific J. Trop. Biomed. 4(1): 918-922. http://dx.doi. org/10.12980/APJTB.4.2014APJTB-2014-0157

-Kolawole OD, Okorie VO, Ogidiowa MT, Adeogun MO (2007). Ethno-Veterinary Practices Amongst Small-Holder Farmers inEkiti State, Nigeria. Afr. J. Trad. 4 (4): 434 - 442. http://dx.doi.org/10.4314/ajtcam.v4i4.31238

- Kumar V, Ravikumar RK (2016). Indigenous Innovations in Livestock production systems: NIF initiatives, In. Sarjan Reddy K, Prasad RMV, Anand Rao K. [Eds] Invited papers: Innovative Designs \& implements for Global Environment and entrepreneurial needs Optimizing Utilitarian Sources, Indigenous, International Livestock Conference \& Expo, $23^{\text {rd }}$ Annual Convention, ISAPM, Hyderabad, India, 28-31 January, Pp. 28-35.

- Kumar V and Ravikumar RK (2016a). Realistic aspiration for livestock health care through indigenous veterinary system in India, Dairy of India 216-17, Sadana Publishers \& Distributors, Ghaziabad, India. Pp. 162-164.

-Kumar V, Chand VS, Zhang L, Hoppers CAO, Zhang W, Esders M, Gupta AK (2013). Grassroots Innovations for Inclusive Development: Need for a Paradigmatic Shift. VIKALPA. 38(3): 103-122.

-Lwoga ET, Ngulube P, Stilwell C (2010). Understanding indigenous knowledge: Bridging the knowledge gap through a knowledge creation model for agricultural development. SA J. Info. Manage. 12(1): 436.

-Manoj Y, Anupama Y, Ekta, G (2012). Ethno-veterinary practices in Rajasthan, India-A Review. Int. Res. J. Biol. Sci. 1(6): 80-82.

- Mazars G (1994). Traditional veterinary medicine in India. Rev. Sci. Tech. Int. Epiz. 13(2): 443-451.

-Mikhaylova AA (2014). Evolution of the innovation process models, International Journal of Econometrics and Financial management: Special issue on geography of innovation and economic clusters. Evidence Russia. 2(4): 119-123.

-Minh TT, Friederichsen R, Neef A, Hoffmann V (2014). Niche action and system harmonization for institutional change: Prospects for demand-driven agricultural extension in Vietnam. J. Rural Stud. 36: 273-284. http://dx.doi. org/10.1016/j.jrurstud.2014.09.008

-Munda S, Pandey R, Bhojne GR, Dakshinkar NP, Kinhekar AS, Kumar V, Ravikumar RK, Kumar V (2016). Indigenous Knowledge Research System [IKRS] for treatment of bloat and its significance towards greenhouse gas emission: Jharkhand, India. Adv. Anim. Vet. Sci. 4(5): 241-249. http:// dx.doi.org/10.14737/journal.aavs/2016/4.5.241.249

-Nabukenya I, Rubaire-Akiiki C, Olila D, Ikwap K, Hoglund J (2014). Ethnopharmacological practices by livestock farmers in Uganda: Survey experiences from Mpigi and Gulu districts. J. Ethnobiol. Ethnomed. 10: 9. http://dx.doi. org/10.1186/1746-4269-10-9

-NJAS (2013). Livestock farming with care: towards sustainable production of animal source. NJAS Wageningen J. Life Sci. 66: 3-5. http://dx.doi.org/10.1016/j.njas.2013.05.009

- Notenbaert A, Pfeifer C, Silvestri S, Herrero M (2016). Targeting, out-scaling and prioritising climate-smart interventions in agricultural systems: Lessons from applying. a generic framework to the livestock sector in sub-Saharan Africa. Agri. Syst. (In press). http://dx.doi.org/10.1016/j. agsy.2016.05.017

-Ogalleh SA, Vogi CR, Eitzinger J, Hauser M (2012). Local perceptions and responses to climate change and variability: The case of Laikipia district, Kenya. Sustainability 4:3302- 
3325. http://dx.doi.org/10.3390/su4123302

-Parthiban R, Vijayakumar S, Prabhu S, Yabesh JGEM (2016). Quantitative traditional knowledge of medicinal plants used to treat livestock diseases from Kudavasaltaluk of Thiruvarur district, Tamil Nadu, India. Revista Brasileira de Farmacognosia.26(1): 109-121. http://dx.doi.org/10.1016/j. bjp.2015.07.016

- Patel JB, Patel S, Patel P, Ravikumar RK, Kinhekar AS, Kumar V, Ingle VC, Awandkar S, Temburne PA and Kumar V (2015). Poultry immunity against Ranikhet Disease Virus (RDV) A Case study of an indigenous poultry medication in village production systems of Maharashtra, India. J. Chem. Pharma. Res. 7(4): 1040-1042.

-Periyaveeturaman C, Selvaraju D, Kinhekar AS, Singh PK, Ravikumar RK, Kumar V (2015). Effiacy of herbal composition against ectoparasite infestation in dogs. Adv. Appl. Sci. Res. 6(8): 242-245.

- Raot US, Parmar M, Patel P, Patel R, Gogoi DM, Patel J, Sivapregasam V, Kumar V, Ravikumar RK, Kumar V (2016). Value Addition of novel herbal livestock medication Mastiherb in treatment of mastitis sustained by creative communities from the regions of Dang, Gujarat. Int. J. Bioresource Stress Manage. 7(3): 501-507.

- Rangnekar DV (2011). Change in animal nutrition research paradigm needed to benefit resource poor livestock producers in countries like India, In. FAO. 2011. Successes and failures with animal nutrition practices and technologies in developing countries. Proceedings of the FAO Electronic Conference, 1-30 September 2010, Rome, Italy. Edited by Harinder P.S. Makkar. FAO Animal Production and Health Proceedings. No. 11. Rome, Italy Pp. 1-6. Accessed at: http:// www.fao.org/3/a-i2270e.pdf.

- Ramkumar S, Rao SVN, Waldie K (2004). Dairy Cattle rearing by landless rural women in Pondicherry: A path to empowerment. Indian J. Gender Studies. 11(2): 205-222. http://dx.doi.org/10.1177/097152150401100204

- Ravikumar RK and Chander M (2011). Livestock extension education activities of the State Departments of Animal Husbandry (SDAH) in India: A case of Tamil Nadu state. Indian J. Anim. Sci. 81 (7): 757-762.

- Ravikumar RK and Kumar V (2015). New frontiers for indigenous knowledge research system [IKRS]: Non Linear Innovation System [NLIS] and Open Source Innovation System [OSIS], In Jaswinder Singh, HK Verma, Navdeep Singh, Simrinder Singh, RajjeshKasrija [Eds] Lead Paper: Technologies and proven practices for sustainable livestock production, Push to the livestock farming through knowledge empowerment of the farmers, First National Conference, SVAHE, Guru Angad Dev Veterinary and Animal Sciences University [GADVASU], Ludhiana, India, 18-20 November, Pp. 239-242.

- Ravikumar RK, Dutta L, Kinhekar AS, Kumar V (2016). People's knowledge for addressing societal needs: Lessons learnt while engaging farming communities as a part of research system. Adv. Anim. Vet. Sci. 4(1s): 1-8. http:// dx.doi.org/10.14737/journal.aavs/2016/4.1s.1.8

- Ravikumar RK, Periyaveeturaman C, Selvaraju D, Kinhekar AS, Dutta L, Kumar V (2016a). Community oriented ectoparasite intervention system: Concepts for on-farm application of indigenous veterinary medication. Adv. Anim. Vet. Sci. 4(1S): 9-19. http://dx.doi.org/10.14737/journal. aavs/2016/4.1s.9.19

- Ravikumar RK, Kinhekar AS, Ingle VC, Sonkusale P, Awandkar
SP, Tembhurne PA, Kumar V (2016b). Effect of Heat Stress on Haematological and Immunological Parameters in Broiler Chicken. Indian J. Vet. Sci. Biotechnol. 11(3): 40-42.

-Ravikumar RK, Choudhary H, Kumar V (2015). Means for retaining farming communities in semi-arid regions of Gujarat state. Agri. Update. 10(2): 158-163. http://dx.doi. org/10.15740/HAS/AU/10.2/158-163

- Ravikumar RK, Dutta L, Kumar V, Kumar V (2015a). Strengthening indigenous veterinary system- An approach for mobilizing community from West Bengal. Asian Academic Res. J. Soc. Sci. Humanities. 1(34): 286-290.

- Ravikumar RK, Kinhekar AS, Sahay NS, Kumar V, Singh PK, Chodvadiya MB, Kumar V (2015b). Methodological Approach for Sustaining Indigenous Veterinary Knowledge of Society: Case Studies to Control of Endoparasite from the Regions of Gandhinagar, Bhavnagar and Junagadh Districts of Gujarat State, India. Indian J. Appl. Res. 5(10): 640-642.

-Ravikumar RK, Kumar V, Choudhary H, Kinhekar A, Kumar V (2015c). Efficacy of indigenous polyherbal ectoparasiticide formulation against Hard tick infestation in cattle (Bos indicus). Ruminant Sci. 4(1): 43-47.

-Richert RM, Cicconi KM, Gamroth MJ, Schukken YH, Stiglbauer KE, Ruegg PL (2013). Risk factors for clinical mastitis, ketosis, and pneumonia in dairy cattle on organic and small conventional farms in the United States. J. Dairy Sci. 96: 1-17. http://dx.doi.org/10.3168/jds.2012-5980

- Ritter RA, Monteiro MVB, Monteiro FOB, Rodrigues ST, Soares ML, Silva JCR, Palha MDC, Biondi GF, Rahal SC, Tourinho MM (2012). Ethnoveterinary knowledge and practices at Colaresisland, Para State, eastern Amazon, Brazil. J. Ethnopharmacol. 144: 346-352. http://dx.doi. org/10.1016/j.jep.2012.09.018

-Sangha KK, Brocque AL, Costanza R, Cadet-James Y (2015). Ecosystems and indigenous well-being: An integrated framework. How rural agricultural development projects (animal production) can use projects benefits for improving the economics states of farmers. Global Ecol. Conservat. 4: 197-206. http://dx.doi.org/10.1016/j.gecco.2015.06.008

-Shamim A, Hassan MU, Yousaf A, Iqbal MF, Zafar MA, Siddique RM, Abubakar M (2015). Occurrence and identification of Emeriaspecies in broiler rearing under traditional system. J. Anim. Sci. Technol. 57: 41. http:// dx.doi.org/10.1186/s40781-015-0074-0

-Shen S, Qian J, Ren J (2010). Ethno-veterinary plant remedies used by Nu people in NW Yunnan of China. J. Ethnobiol. Ethnomed. 6: 24. http://dx.doi.org/10.1186/1746-4269-624

-Simula H, Hossain M, Halme M (2015). Frugal and reverse innovations- Quo Vadis? Special section: Design for wellbeing. Current Sci. 109(9): 1567-1572.

-Singh RK, Sureja AK (2006). Centurion women and diverse knowledge systems. Indian J. Tradit. Knowl. 5(3): 413-419.

- Surtia G, Panchal P, Patel M, Ravikumar RK, Kumar V (2016). Improving livelihood initiatives through environmental friendly solutions derived from livestock product. Int. J. Sci. Environ. Technol. 5(2): 658-665.

-Singh SK and Chauhan J (2010). Perceived effectiveness of ITK among livestock owners. Indian Res. J. Ext. Edu. 10(1): 1215.

-Tiwari L and Pande PC (2010). Ethnoveterinary medicines in Indian perspective: Reference to Uttarakhand, Himalaya. Indian J. Tradit. Knowl. 9 (3): 611-617. 
-Usha S, Rajasekaran C, Siva R (2016).Ethno-veterinary medicine of the Shervaroy Hills of Eastern Ghats, India as alternative medicine for animals. J. Tradit. Complement. Med. 6: 118125. http://dx.doi.org/10.1016/j.jtcme.2014.11.013

-Verma RK (2014). An ethnobotanical study of plants used for the treatment of livestock diseases in Tikamgarh District of Bundelkhand, Central India. Asian Pac. J. Trop. Biomed. 4(Suppl 1): S460-S467. http://dx.doi.org/10.12980/ APJTB.4.2014C1067
-Visvesvaran S and Thirumalaiswamy T (2015). Ethno-veterinary practices adopted during an epidemic outbreak of Foot and Mouth Disease among cattle in Sirkazhi and adjoining villages of Nagapattinam district of Tamil Nadu, India. Int. J. Pharmacol. Clin. Sci. 4(2): 23-34.

-Yacob AN, Luck T, Lee, Ibrahim HB (2012). Conservation, Consolidation and Economic Generation of Indigenous Community Agriculture Sustainable Food Yielding Reforestation. Procedia Soc. Behavior. Sci. 68: 319 - 329. 